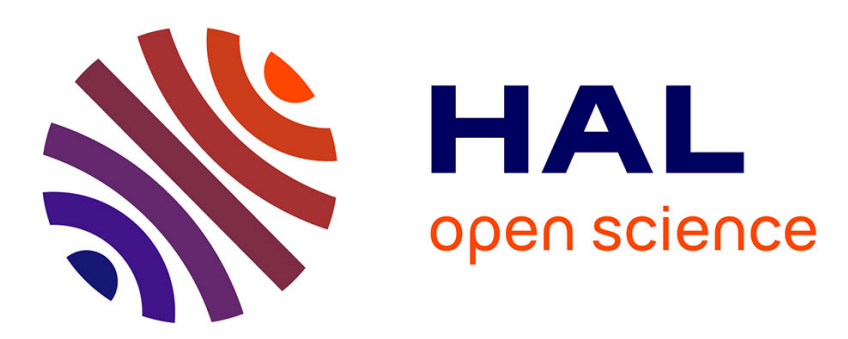

\title{
Environmental and dietary exposure of young children to inorganic trace elements
}

Philippe Glorennec, Jean-Paul Lucas, Anne-Camille Mercat, Alain-Claude Roudot, Barbara Le Bot

\section{- To cite this version:}

Philippe Glorennec, Jean-Paul Lucas, Anne-Camille Mercat, Alain-Claude Roudot, Barbara Le Bot. Environmental and dietary exposure of young children to inorganic trace elements. Environment International, 2016, 97, pp.28-36. 10.1016/j.envint.2016.10.009 . inserm-01404061

\section{HAL Id: inserm-01404061 https://www.hal.inserm.fr/inserm-01404061}

Submitted on 28 Nov 2016

HAL is a multi-disciplinary open access archive for the deposit and dissemination of scientific research documents, whether they are published or not. The documents may come from teaching and research institutions in France or abroad, or from public or private research centers.
L'archive ouverte pluridisciplinaire HAL, est destinée au dépôt et à la diffusion de documents scientifiques de niveau recherche, publiés ou non, émanant des établissements d'enseignement et de recherche français ou étrangers, des laboratoires publics ou privés. 


\section{Environmental and dietary exposure of young children to inorganic trace elements}

Philippe Glorennec ${ }^{1,2}$, Jean-Paul Lucas ${ }^{3,4}$, Anne-Camille Mercat ${ }^{1,2,5}$, Alain-Claude Roudot ${ }^{5}$, Barbara le Bot $^{1,2}$

${ }^{1}$ EHESP, School of Public Health, Rennes, Sorbonne Paris Cité - Avenue du Professeur Léon-Bernard, CS 74312, 35043 Rennes cedex, France.

${ }^{2}$ Irset Inserm, UMR 1085-Institut de Recherche sur la Santé, I'Environnement et le Travail, Rennes, France.

${ }^{3}$ Paris Est University - CSTB - Scientific and Technical Building Centre, Marne la Valléecedex 2, France

${ }^{4}$ University of South Brittany, UMR 6205, LMBA, F-56000 Vannes, France

${ }^{5}$ Laboratoire d'Evaluation du Risque Chimique pour le Consommateur (LERCCo), Université Bretagne Loire - Université de Bretagne Occidentale, 6 Av. Victor Le Gorgeu, CS93837, Brest Cedex 3, 29238, France

$\left(^{*}\right)$ Correspondingauthor

E-mail address: Philippe.glorennec@ehesp.fr (Philippe Glorennec)

Phone: +33299022680

Fax: +33299022929 


\begin{abstract}
Children are exposed to toxic metals and metalloids via their diet and environment. Our objective was to assess the aggregate chronic exposure of children aged 3-6 years, living in France, to $A s, C d, C r, C u$, $\mathrm{Mn}, \mathrm{Pb}, \mathrm{Sb}, \mathrm{Sr}$, and $\mathrm{V}$ present in diet, tap water, air, soil and floor dust in the years 2007-2009. Dietary data came from the French Total Diet Study, while concentrations in residential tap water, soil and indoor floor dust came from the 'Plomb-Habitat' nationwide representative survey on children's lead exposure at home. Indoor air concentrations were assumed to be equal to outdoor air concentrations, which were retrieved from regulatory measurements networks. Human exposure factors were retrieved from literature. Data were combined with Monte Carlo simulations. Median exposures were 1.7, 0.3, 10.2, 34.1, 60.3, 0.7, 0.1, 44.3, 1.5 and 95th percentiles were 4.4, 0.5, 15.8, $61.3,98.3,2.5,0.1,111.1,2.9 \mu \mathrm{g} / \mathrm{kg} \mathrm{bw} / \mathrm{d}$ for $\mathrm{As}, \mathrm{Cd}, \mathrm{Cr}, \mathrm{Cu}, \mathrm{Mn}, \mathrm{Pb}, \mathrm{Sb}, \mathrm{Sr}$, and $\mathrm{V}$ respectively. Dietary exposures dominate aggregate exposures, with the notable exception of $\mathrm{Pb}$ - for which soils and indoor floor dust ingestion contribute most at the 95th percentile. The strengths of this study are that it aggregates exposures that are often estimated separately, and uses a large amount of representative data. This assessment is limited to main diet and residential exposure, and does not take into account the relative bioavailability of compounds. These results could be used to help target prevention strategies.
\end{abstract}

Keywords: Aggregate exposure; Metal; Total diet study; Residential exposure; Public health 


\section{Introduction}

Many metals are known to have adverse impacts on human health via various toxicological mechanisms. These have also been subject to exposure surveillance indicating that reference values may be reached for certain populations - for instance for lead, cadmium and Arsenic (WHO 2015). This is particularly true of lead: in France in 2008-2009, for example, more than half of young children had blood lead levels above the No Observed Effect Level(Etchevers et. al 2014). Because they are subject to developmental toxicity (Grandjean et. al 2008) and because their lower body weight and more intense hand to mouth activity means they are most exposed, children are of particular concern. Metals and metalloids are widely distributed and ubiquitous in the environment, so that people are exposed via both food and environment.

Biomonitoring studies are ideal for taking into account all sources of exposure without allowing source apportionment, while indirect methods modeling doses from contamination and consumption data enableestimation of the specific contribution made by a given exposure medium(Lioy and Rappaport 2011), which is useful with a view to prevention measures. However,given the amount of data that are required, many indirect exposure assessments are dedicated to one particular source or media (diet, water, soil, dust...) of exposure. This is true of Total Diet Studies (TDS), designed to assess dietary exposure to many compounds, as well as studies designed to address a particular environmental situation such as an industrial setting. The consequence is that there is often a choice to be made between knowledge of overall, or aggregate, exposure, and awareness of the significance of different media and sources of exposure. The result is that there are very few indirect exposure assessments taking into account most pathways of exposures for the general population, and then quantifying the relative importance of each one. Aggregate exposure assessment allows such a global view, which could reveal useful in regulatory context for setting a media standard accounting for others.

In the present study, our objective is twofold. It is to assess, for 3-6 year-old children living in France, firstly aggregate chronic exposure to Arsenic (As), Cadmium (Cd), Chromium (Cr), Copper (Cu), Manganese ( $\mathrm{Mn}$ ), Lead ( $\mathrm{Pb})$, Antimony (Sb), Strontium ( $\mathrm{Sr}$ ) and Vanadium ( $\mathrm{V}$ ) and secondly, to identify the main contributors to exposure to these toxic metals and metalloids. We focused on the general population, living aside particular situations such as local contamination or specific consumption habits. The ultimate goal is to help identifying the relevant pathways of exposure for young children, which could be useful for setting dietary or environmental standards.

We chose these metals because of their toxicity and because their contamination data were available at nationwide scale,for both food and residential environment. Other environments such as public living places were not included in the assessment. 


\section{Material and methods}

\subsection{Assumptions}

We calculated external exposures, assuming a total absorption of contaminant by inhalation and ingestion pathways. We did not take into account the dermal route,since this is assumed to be negligible for inorganic metals and metalloids (Nordberg et. al 2014). Children's environmental exposure was assumed to be equivalent to residential exposure, i.e. at home where they spend the largest amount of time. As indoor air data were not available, indoor air concentrations were assumed to be equivalent to outdoor air concentrations. Dietary exposure was limited to food items included in the French Total Diet Study (Anses 2011). As we focused on chronic exposures, we did not take into account the temporal variability of exposures. In order to give an idea of the possible risk for children, a comparison is made when possible, between the aggregate exposure and an international Tolerable Daily Intake (TDI). This comparison is to be taken with care, because a total absorption was supposed whatever considered route of exposure.

\subsection{Exposure model}

We aggregated external chronic exposures via oral (ingestion) and respiratory (breathing) routes by summing them in a probabilistic framework. Exposure of individual $i$ to contaminant $j$ was calculated using Equation 1.

$\mathrm{E}_{\mathrm{i}, j}=\operatorname{Eresp}_{i, j}+\operatorname{Eing}_{i, j}$ Equation (1)

With $E_{i, j}$ : Daily exposure of individual $i$ to contaminant $j$, Eresp $p_{i, j}$ : daily respiratory exposure of individual $i$ to contaminant $j$ ( $\mu g$ of contaminant $/ \mathrm{kg} b w / d$ ), Eing $\mathrm{b}_{i, j}$ : daily ingestion exposure of individual $\mathrm{i}$ to contaminant $\mathrm{j}$ ( $\mu \mathrm{g}$ of contaminant $/ \mathrm{kg} \mathrm{bw} / \mathrm{d}$ ).

Respiratory exposure was calculated using Equation 2.

$$
\operatorname{Eresp}_{i, j}=\frac{C_{j} \times V_{i}}{B W_{i}} \quad \text { Equation (2) }
$$

With $V_{i}$ : total daily respired volumeof individual $i\left(\mathrm{~m}^{3} / \mathrm{d}\right), \mathrm{C}_{\mathrm{j}}$ : Air concentration of contaminant $\mathrm{j}(\mu \mathrm{g}$ contaminant $\left./ \mathrm{m}^{3}\right), \mathrm{BW}_{\mathrm{i}}$ : Body Weight of individual $\mathrm{i}(\mathrm{kg} \mathrm{bw})$.

Ingestion exposure was calculated using Equation 3.

Eing $_{i, j}=$ Ediet $_{i, j}+$ Ewater $_{i, j}+$ Edust $_{i, j}+$ Esoil $_{i, j} \quad$ Equation (3)

With Ediet ${ }_{i, j}$ : dietary exposure of individual $i$ to contaminant $\mathrm{j}$ ( $\mu \mathrm{g}$ contaminant/kg bw/d), Ewater $\mathrm{r}_{\mathrm{i}, \mathrm{j}}$, Edust $_{i, j}$, and $\mathrm{E}_{\text {soi }} \mathrm{i}_{\mathrm{i}, \mathrm{j}}$ : exposure of individual $\mathrm{i}$ to contaminant $\mathrm{j}$ in drinking water (tap), dust and soil, respectively ( $\mu \mathrm{g}$ contaminant/kg bw/d). 
Dietary exposure was calculated using Equation 4.

Ediet $_{i, j}=\frac{\sum_{k=1}^{n} Q_{k, i} \times C_{k, j}}{B W_{i}}$

Equation (4)

With Ediet $\mathrm{i}_{\mathrm{i}, \mathrm{j}}$ : dietary exposure of individual $\mathrm{i}$ to contaminant $\mathrm{j}$ ( $\mu \mathrm{g}$ contaminant/kg bw/d), $\mathrm{n}$ : number of food items in the diet, $Q_{k, i}$ : food $k$ consumption by individual $i\left(g\right.$ food/d), $C_{k, j}$ : Concentration of contaminant $\mathrm{j}$ for food $\mathrm{k}$ ( $\mu \mathrm{g}$ contaminant/g food).

Tap water exposure was calculated as follows, using Equation 5. NB: bottled water was treated as a food item.

Ewater $_{i, j}=\frac{Q_{w i} \times C_{j}}{B W_{i}} \quad$ Equation (5)

With Ewater $r_{i, j}$ : tap water exposure of individual $i$ to contaminant $j$ ( $\mu g$ contaminant/kg bw/d), $Q w_{i}$ : tap water consumption of individual $\mathrm{i}(\mathrm{L} / \mathrm{d}), \mathrm{C}_{\mathrm{j}}$ : tap water concentration in contaminant $\mathrm{j}(\mu \mathrm{g}$ contaminant/L).

Exposure to dust was calculated as follows, using Equation 6.

Edust $_{i, j}=\frac{\frac{C_{s, j}}{L_{s}} \times Q_{d i}}{B W_{i}} \quad$ Equation (6)

With Edust $\mathrm{i}_{\mathrm{j}, \mathrm{j}}$ : dust exposure for individual $\mathrm{i}$ to contaminant $\mathrm{j}$ ( $\mu \mathrm{g}$ contaminant $/ \mathrm{kg} \mathrm{bw} / \mathrm{d}$ ), $\mathrm{Q}_{\mathrm{di}}$ : dust ingestion rate for individual $i\left(m g\right.$ dust/d), $C_{s, j}$ : surface $s$ concentration of contaminant $j(\mu g$ contaminant $\left./ \mathrm{m}^{2}\right)$, $\mathrm{L}_{\mathrm{s}}$ : dust loading of surface $\mathrm{s}\left(\mathrm{mg}\right.$ dust $\left./ \mathrm{m}^{2}\right)$.

Exposure to soil was calculated as follows, using Equation 7.

$$
E s_{i, j}=\frac{Q_{s i} \times C_{j} \cdot 10^{-3}}{B W i} \text { Equation (7) }
$$

With Esoil $\mathrm{l}_{\mathrm{i}, \mathrm{j}}$ : soil exposure for individual $\mathrm{i}$ to contaminant $\mathrm{j}$ ( $\mu \mathrm{g}$ contaminant $/ \mathrm{kg} \mathrm{bw} / \mathrm{d}$ ), $\mathrm{Q}_{\mathrm{si}}$ : soil ingestion rate for individual $\mathrm{i}\left(\mathrm{mg}\right.$ dust/d), $\mathrm{C}_{\mathrm{j}}$ : soil concentration of contaminant $\mathrm{j}$ ( $\mu \mathrm{g}$ contaminant/g of soil).

\subsection{Human exposure factors: consumption, intake rates, body weights and dust loadings}

The food and water consumption of children aged 3-6 years was retrieved from the corresponding 244 individual data sets from the French 'INCA2' representative food consumption survey, which recorded food habits over a period of seven consecutive days (Lioret et. al 2010). Body weight data 
werealso available from this survey. Total daily respired volumes, as well as dust and soil intake rates, were retrieved from the exposure factors handbook (EPA 2011). Mean and $95^{\text {th }}$ percentiles were 10.1, $13.8 \mathrm{~m}^{3}$ (air)/d; 60, $100 \mathrm{mg}$ (dust)/d; 50, $200 \mathrm{mg}$ (soil)/d. We used the normal (left truncated to zero) shapes of distributions indicated in the exposure factors handbook (lognormal for dust intake as stated by Ozkaynak(Ozkaynak et. al 2011)). Dust loading was estimated by weighting geometric means and standard deviation indicated in (Giovannangelo et. al 2007), and resulted in $255.3 \mathrm{mg}$ (dust) $/ \mathrm{m}^{2}$ with geometric standard deviation of $3.23 \mathrm{mg}$ (dust) $/ \mathrm{m}^{2}$.

\subsection{Food and environment contamination data}

Food contamination data are from the last French Total Diet Study: the most consumed (consumer rate of at least 5\%) foods identified in consumer survey(Lioret et al. 2010)plus the main known or assumed food contributors to exposure were selected(Anses 2011). It led to 212 food items of 41 food groups covering around $90 \%$ of the whole diet (Arnich et. al 2012). 19,830 of these food items were sampled in eight metropolitan regions, over two different seasons, between June 2007 and January 2009 in order to reflect chronic exposure. Before analysis, they were groups up to 15 of equal weight of the same food, taking into account the market share, origin, species, packaging etc.and prepared as consumed (Sirot et. al 2009).

Environmental data are from the nationwide Plomb-Habitat survey in France (Lucas et. al 2012), in which other metals were also measured in water(Le Bot et. al 2016), as well as in soil and dust (Glorennec et. al 2012). This sampling was completed between October 2008 and August 2009, and was designed to be representative of children living in France (Etchevers et al. 2014), and of their exposures. Tap water was sampled in the kitchen, after flushing and at stagnation time of 30' (Le Bot et al. 2016). Floor dust was sampled with a hand wipe at the child's indoor play area. Soil was sampled using a ring at the child's outdoor play area (Glorennec et al. 2012). More details about sampling have been extensively described elsewhere (Lucas et al. 2012). Data from the 215 children aged 3 to 6 years were used, alongside theircorresponding sampling weights, adjusted to represent the population of children living in France (Oulhote et. al 2013).

Because no representative French survey exists for these compounds in air, we used local data from air quality monitoring regional approved associations (http://www.atmo-france.org/fr). Urban air concentrations for 2007-2009 were retrieved, providing 36 data sets from 22 cities for As, 37 data sets from 23 cities for $\mathrm{Cd}$, 8 data sets from six cities for $\mathrm{Cr}$, ten data sets from six cities for $\mathrm{Cu}$, seven data sets from three cities for $\mathrm{Mn}, 39$ data sets from 24 cities for $\mathrm{Pb}$, eight data sets from three cities for $\mathrm{Sb}$ andseven data sets from three cities for $\mathrm{V}$. For $\mathrm{Sr}$, in the absence of relevant data, we used two data sets from 1 U.S. city (Dzubay and Stevens 1975). Concentrations ranged from 0.2 to $10.6 \mathrm{ng} / \mathrm{m}^{3}$ for As, 0.04 to $0.5 \mathrm{ng} / \mathrm{m}^{3}$ for $\mathrm{Cd}, 2.1$ to $4.1 \mathrm{ng} / \mathrm{m}^{3}$ for $\mathrm{Cr}, 7.1$ to $22.4 \mathrm{ng} / \mathrm{m}^{3}$ for $\mathrm{Cu}, 6.1$ to $11.3 \mathrm{ng} / \mathrm{m}^{3}$ for $\mathrm{Mn}, 1$ to $13.3 \mathrm{ng} / \mathrm{m}^{3}$ for $\mathrm{Pb}, 1.2$ to $2.9 \mathrm{ng} / \mathrm{m}^{3}$ for Sb, 4 to $100 \mathrm{ng} / \mathrm{m}^{3}$ for Sr and 1 to $3.3 \mathrm{ng} / \mathrm{m}^{3}$ for V. By default, uniform distributions were used between Min and Max of observed values.

\subsection{Computation}

All data were combined with Monte Carlo simulations $(n=100000)$, taking into account the sampling designs of the food consumption and Plomb-Habitatrepresentative surveys with corresponding sampling weights. Simulations were conducted using Crystal Ball@ 11.1 software (Oracle Corporation, CA). Concentrations below the limits of detection (LoD) or quantification (LoQ) were replaced by LoD/2 or LoQ/2 respectively, leading to a middle bound estimate. Replacements by 0 (lower bound) 
or LoD or LoQ (upper bound) were used for sensitivity analysis. Potential correlations between data were managed as follows:correlations were tested between metals concentrations in water, dust, soil, age and region for the Plomb-Habitatsurvey, as well as between region, age, water consumption and dietary intake. Correlations with $p$-values $<0.10$ were included in the simulation process, as was a linear correlation ( $r=0.14)$ between dust load and surface concentration previously described for $\mathrm{Pb}$ (Glorennec et. al 2005).Contributions to exposure to each food group were assessed by dividing population averaged food group intake by population averaged total intake. 


\section{Results and discussion}

\subsection{Aggregate exposure and relative importance of exposure pathways}

The simulated median chronic exposures are displayed by pathway on Figure 1. Total exposure levels were $1.7,0.3,10.2,34.1,60.3,0.7,0.08,44.3,1.5 \mu \mathrm{g} / \mathrm{kg} \mathrm{bw} / \mathrm{d}$ and 95 th percentiles were 4.4, 0.5, $15.8,61.3,98.3,2.5,0.12,111.1,2.9 \mu \mathrm{g} / \mathrm{kg} \mathrm{bw} / \mathrm{d}$ for $\mathrm{As}, \mathrm{Cd}, \mathrm{Cr}, \mathrm{Cu}, \mathrm{Mn}, \mathrm{Pb}, \mathrm{Sb}, \mathrm{Sr}$, and $\mathrm{V}$ respectively.

The figures shown in Figure 1 were obtained using the middle bound method. With lower bound (values $<$ LoQ replaced by 0 , results not shown) the differences of median and $95^{\text {th }}$ percentile exposures were insignificant. Differences were slightly higher when using the upper bound estimates (values $<$ LoQ replaced by $L Q$, results not shown), with a $10 \%$ difference for the highest (for median estimate) for $\mathrm{Pb}$, and a $20 \%$ difference for $\mathrm{Sb}$ and $\mathrm{V}$. In the following results, only middle bound estimates will be presented and discussed.

Figure 1 also shows that diet was the major contributor of exposure to metals, with the exception of lead, where residential exposure was the main source for the $95^{\text {th }}$ percentile. The particular case of lead is discussed later in the article. For other elements, diets constituted at least at $95 \%$ of exposure for $\mathrm{As}, \mathrm{Cd}, \mathrm{Cr}, \mathrm{Cu}$ and $\mathrm{Mn}$. For Sr the diet contributed 89\%, and tap water 9\%; for $\mathrm{V}$ the diet contributed $86 \%$ and soil ingestion $9 \%$. Sb exposures were mainly (77\%) via diet but dust, soil and tap water complemented this with contributions of $11 \%, 6 \%$ and $5 \%$ respectively. In any case, air was negligible as a pathway of exposure. Indoor sources were however not taken into account in this assessment. In particular, indoor exposure to tobacco smoke could be of concern for $\mathrm{As}, \mathrm{Cd}$ and $\mathrm{Pb}$. Air contribution remained negligible (up to $2 \%$ for $\mathrm{Pb}$ ) when replacing the air concentrations of these pollutants with indoor concentrations in smokers' homes (Bonanno et. al 2001).

In the TDS several samples of a food item were purchased, and pooled before analysis in order to control costs. This pooling, rather than affecting estimation of the mean estimate, underestimates the variability of dietary exposures. Environmental samples were not pooled before analysis (average dust concentration from rooms was used) so variability is not underestimated. This pooling of food samples alone could result in an underestimation of the dietary contribution, for those children most exposed. 


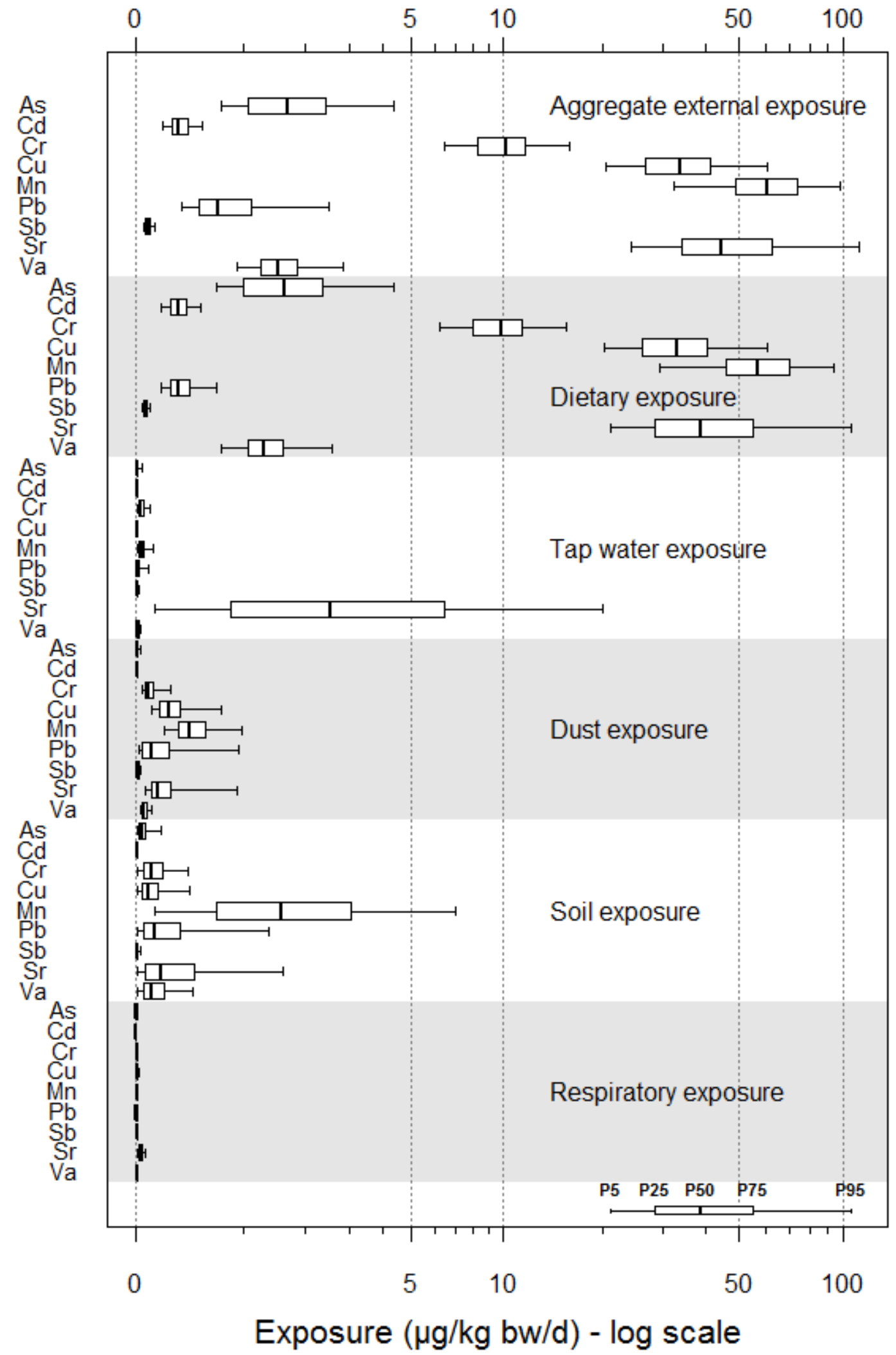

Fig.1. Chronic exposure of 3-6 year-old children to inorganic compounds, France 2007-2009.MB: middle bound estimate: concentrations $<$ LoQ were replaced by LoQ/2. 


\subsection{Dietary exposures}

With the exception of lead for those most exposed to it, diet is actually the predominant exposure. The mean contribution of each food group is indicated in Table 1 for median dietary intake, and in Table 2 for the $10 \%$ most exposed by diet.

\section{Arsenic}

Median and P95 children's total and dietary exposure estimates were 1.7, 4.4, 1.6 and $4.3 \mu \mathrm{g} / \mathrm{kg}$ bw/d respectively. More than $95 \%$ of total exposure came via diet. This result is inagreement with published data for this age group: Arnich obtained $1.2 \mu \mathrm{g} / \mathrm{kg} \mathrm{bw} / \mathrm{d}$ for French children between 3 and 17 years old (Arnich et al. 2012). As it is known that daily intake decreases with age(EFSA 2009c), this is a good level of agreement. The European Food Safety Authority (EFSA) gave a mean value between 1.6 and $1.9 \mu \mathrm{g} / \mathrm{kg} \mathrm{bw} / \mathrm{d}$ (LB-UB) for the French population, and estimated from Italian population studies, that children's exposure was twice the level of adults (EFSA 2009c) - meaning that our results seem slightly lower than expected. Rose found $2.8 \mu \mathrm{g} / \mathrm{kg} \mathrm{bw} / \mathrm{d}$ for United Kingdom (UK) toddlers (mean UB value) and Wilhelm, $0.4 \mu \mathrm{g} / \mathrm{kg}$ bw/d for German children (Rose et. al 2010; Wilhelm et. al 2003). The most contributing food was fish ( $47 \%$ - increasing to $64 \%$ for the P90 population), then milk (7\%) and shellfish (6\%), which was also noticed in the UK and Catalonia, Spain (Llobet et. al 2003; Rose et al. 2010). Compared with the epidemiological BMDL considered by the EFSA as a reference value (from 0.3 to $8 \mu \mathrm{g} / \mathrm{kg}$ bw/d) (EFSA 2009c), these exposures are of great concern for children's health. However, when using these results from a risk assessment perspective it is important to bear in mind that our evaluation is very protective because the toxicological threshold used is for inorganic arsenic, whereas the exposure is expressed in total arsenic because published concentration values taking into account arsenic speciation are rare.Inorganic arsenic generally represents around $6 \%$ of the total arsenic in human diet, less than 5\% for seafood and fish for instance (Leufroy et. al 2011).

\section{Cadmium}

Median and P95 children's total and dietary exposure estimates were $0.32,0.53,0.31$ and $0.52 \mu \mathrm{g} / \mathrm{kg}$ bw/d respectively. More than $97 \%$ of total exposure came via diet. For French children, between 3 and 17 years old, dietary mean exposure was estimated at $0.24 \mu \mathrm{g} / \mathrm{kg}$ bw/d (Arnich et al. 2012). Schrey obtained a mean value of $0.4 \mu \mathrm{g} / \mathrm{kg}$ bw/d for German children aged 1 to 5 years(Schrey et. al 2000), while Rose obtained a mean exposure value between 0.37 and $0.45 \mu \mathrm{g} / \mathrm{kg}$ bw/d (LB-UB) for toddlers (Rose et al. 2010) in the UK. All these values are in agreement. The most contributing foods were potatoes $(14 \%)$, then bread $(10 \%)$, noodles or pasta $(8 \%)$ and vegetables $(8 \%)$. Spinach is the most contributing product in the vegetable category ( $38 \%$ of the category) due to its high contamination $(73 \mu \mathrm{g} / \mathrm{kg})$ in comparison to the median contamination of food $(3 \mu \mathrm{g} / \mathrm{kg})$. Given the EFSA's TWI (Tolerable Weekly Intake) (EFSA 2009a)for cadmium $(2.5 \mu \mathrm{g} / \mathrm{kg} \mathrm{bw} / \mathrm{w})$, the children's exposure is of great concern $(2.1 \mu \mathrm{g} / \mathrm{kg} \mathrm{bw} / \mathrm{w}$ for median and $3.5 \mu \mathrm{g} / \mathrm{kg} \mathrm{bw} / \mathrm{w}$ for P95 in this study), even if potential health consequences are not immediate due to cumulative toxicity. 


\begin{tabular}{|c|c|c|c|c|c|c|c|c|c|}
\hline Food category & As & Cd & $\mathrm{Cr}$ & $\mathrm{Cu}$ & $M n$ & $\mathrm{~Pb}$ & Sb & $\mathrm{Sr}$ & $\mathbf{v}$ \\
\hline Alcoholic drinks & $<1 \%$ & $<1 \%$ & $<1 \%$ & $<1 \%$ & $<1 \%$ & $<1 \%$ & $<1 \%$ & $<1 \%$ & $<1 \%$ \\
\hline Biscuits or crackers and bars & $1 \%$ & $6 \%$ & $3 \%$ & $5 \%$ & $8 \%$ & $3 \%$ & $4 \%$ & $2 \%$ & $3 \%$ \\
\hline Bread and dry bread & $2 \%$ & $10 \%$ & $3 \%$ & $5 \%$ & $14 \%$ & $6 \%$ & $2 \%$ & $2 \%$ & $5 \%$ \\
\hline Butter & $<1 \%$ & $<1 \%$ & $3 \%$ & $<1 \%$ & $<1 \%$ & $<1 \%$ & $<1 \%$ & $<1 \%$ & $1 \%$ \\
\hline Cereals & $<1 \%$ & $1 \%$ & $2 \%$ & $<1 \%$ & $2 \%$ & $<1 \%$ & $<1 \%$ & $<1 \%$ & $<1 \%$ \\
\hline Cheese & $2 \%$ & $1 \%$ & $6 \%$ & $1 \%$ & $<1 \%$ & $3 \%$ & $3 \%$ & $4 \%$ & $4 \%$ \\
\hline Chocolate & $1 \%$ & $2 \%$ & $2 \%$ & $5 \%$ & $6 \%$ & $2 \%$ & $2 \%$ & $2 \%$ & $2 \%$ \\
\hline Coffee & $<1 \%$ & $<1 \%$ & $<1 \%$ & $<1 \%$ & $<1 \%$ & $<1 \%$ & $<1 \%$ & $<1 \%$ & $<1 \%$ \\
\hline Condiments and sauces & $<1 \%$ & $2 \%$ & $1 \%$ & $<1 \%$ & $<1 \%$ & $1 \%$ & $<1 \%$ & $<1 \%$ & $3 \%$ \\
\hline Delicatessen & $2 \%$ & $1 \%$ & $3 \%$ & $3 \%$ & $<1 \%$ & $3 \%$ & $2 \%$ & $<1 \%$ & $4 \%$ \\
\hline Desserts, puddings and milk jelly & $2 \%$ & $3 \%$ & $4 \%$ & $5 \%$ & $3 \%$ & $2 \%$ & $4 \%$ & $2 \%$ & $2 \%$ \\
\hline Dried fruits and oilseeds & $<1 \%$ & $<1 \%$ & $<1 \%$ & $<1 \%$ & $<1 \%$ & $<1 \%$ & $<1 \%$ & $<1 \%$ & $<1 \%$ \\
\hline Dried vegetables & $<1 \%$ & $<1 \%$ & $<1 \%$ & $2 \%$ & $2 \%$ & $<1 \%$ & $<1 \%$ & $1 \%$ & $<1 \%$ \\
\hline Eggs and derivatives & $<1 \%$ & $<1 \%$ & $<1 \%$ & $<1 \%$ & $<1 \%$ & $<1 \%$ & $<1 \%$ & $<1 \%$ & $<1 \%$ \\
\hline Fish & $47 \%$ & $1 \%$ & $2 \%$ & $1 \%$ & $<1 \%$ & $<1 \%$ & $2 \%$ & $2 \%$ & $1 \%$ \\
\hline Foods for special dietary needs & $<1 \%$ & $<1 \%$ & $<1 \%$ & $<1 \%$ & $<1 \%$ & $<1 \%$ & $<1 \%$ & $<1 \%$ & $<1 \%$ \\
\hline Fresh soft drinks & $3 \%$ & $1 \%$ & $4 \%$ & $3 \%$ & $6 \%$ & $11 \%$ & $6 \%$ & $6 \%$ & $7 \%$ \\
\hline Fruits & $1 \%$ & $2 \%$ & $3 \%$ & $6 \%$ & $6 \%$ & $4 \%$ & $5 \%$ & $4 \%$ & $3 \%$ \\
\hline Ice cream and frozen desserts & $<1 \%$ & $<1 \%$ & $1 \%$ & $2 \%$ & $1 \%$ & $1 \%$ & $1 \%$ & $<1 \%$ & $<1 \%$ \\
\hline Margarine & $<1 \%$ & $<1 \%$ & $<1 \%$ & $<1 \%$ & $<1 \%$ & $<1 \%$ & $<1 \%$ & $<1 \%$ & $<1 \%$ \\
\hline Meat & $2 \%$ & $<1 \%$ & $4 \%$ & $3 \%$ & $<1 \%$ & $3 \%$ & $3 \%$ & $<1 \%$ & $1 \%$ \\
\hline Milk & $7 \%$ & $4 \%$ & $13 \%$ & $3 \%$ & $<1 \%$ & $15 \%$ & $6 \%$ & $7 \%$ & $12 \%$ \\
\hline Mixed dishes & $3 \%$ & $7 \%$ & $4 \%$ & $5 \%$ & $5 \%$ & $4 \%$ & $5 \%$ & $4 \%$ & $5 \%$ \\
\hline Offal & $<1 \%$ & $<1 \%$ & $<1 \%$ & $3 \%$ & $<1 \%$ & $<1 \%$ & $<1 \%$ & $<1 \%$ & $<1 \%$ \\
\hline Oil & $<1 \%$ & $<1 \%$ & $4 \%$ & $<1 \%$ & $<1 \%$ & $<1 \%$ & $<1 \%$ & $<1 \%$ & $<1 \%$ \\
\hline Other hot drinks & $<1 \%$ & $<1 \%$ & $<1 \%$ & $<1 \%$ & $<1 \%$ & $<1 \%$ & $<1 \%$ & $<1 \%$ & $<1 \%$ \\
\hline Pasta & $<1 \%$ & $8 \%$ & $5 \%$ & $14 \%$ & $9 \%$ & $1 \%$ & $6 \%$ & $3 \%$ & $2 \%$ \\
\hline Pastries and cakes & $1 \%$ & $3 \%$ & $4 \%$ & $4 \%$ & $4 \%$ & $2 \%$ & $9 \%$ & $2 \%$ & $2 \%$ \\
\hline Pastries (croissants, etc.) & $<1 \%$ & $3 \%$ & $3 \%$ & $2 \%$ & $4 \%$ & $2 \%$ & $2 \%$ & $<1 \%$ & $4 \%$ \\
\hline Pizzas, quiches and savory pastries & $1 \%$ & $2 \%$ & $1 \%$ & $1 \%$ & $2 \%$ & $<1 \%$ & $1 \%$ & $1 \%$ & $2 \%$ \\
\hline Potatoes and similar & $1 \%$ & $14 \%$ & $3 \%$ & $5 \%$ & $4 \%$ & $3 \%$ & $2 \%$ & $2 \%$ & $2 \%$ \\
\hline Poultry and game & $<1 \%$ & $<1 \%$ & $2 \%$ & $1 \%$ & $<1 \%$ & $<1 \%$ & $<1 \%$ & $<1 \%$ & $<1 \%$ \\
\hline Rice and wheat & $1 \%$ & $2 \%$ & $3 \%$ & $4 \%$ & $5 \%$ & $<1 \%$ & $3 \%$ & $<1 \%$ & $2 \%$ \\
\hline Sandwich, snack & $<1 \%$ & $<1 \%$ & $<1 \%$ & $<1 \%$ & $1 \%$ & $<1 \%$ & $<1 \%$ & $<1 \%$ & $<1 \%$ \\
\hline Shellfish and mollusk & $6 \%$ & $2 \%$ & $<1 \%$ & $<1 \%$ & $<1 \%$ & $1 \%$ & $<1 \%$ & $2 \%$ & $<1 \%$ \\
\hline Soup and stock & $1 \%$ & $3 \%$ & $2 \%$ & $3 \%$ & $2 \%$ & $4 \%$ & $3 \%$ & $3 \%$ & $3 \%$ \\
\hline Stewed fruit and cooked fruit & $<1 \%$ & $3 \%$ & $2 \%$ & $2 \%$ & $2 \%$ & $5 \%$ & $3 \%$ & $1 \%$ & $<1 \%$ \\
\hline Sugar and derivatives & $<1 \%$ & $2 \%$ & $<1 \%$ & $<1 \%$ & $<1 \%$ & $<1 \%$ & $7 \%$ & $<1 \%$ & $<1 \%$ \\
\hline Ultra-fresh dairy & $2 \%$ & $2 \%$ & $5 \%$ & $1 \%$ & $<1 \%$ & $4 \%$ & $4 \%$ & $3 \%$ & $4 \%$ \\
\hline Vegetables (excluding potatoes) & $1 \%$ & $8 \%$ & $3 \%$ & $5 \%$ & $8 \%$ & $6 \%$ & $4 \%$ & $8 \%$ & $4 \%$ \\
\hline Bottled waters & $4 \%$ & $1 \%$ & $1 \%$ & $1 \%$ & $<1 \%$ & $5 \%$ & $5 \%$ & $33 \%$ & $13 \%$ \\
\hline
\end{tabular}

Table 1.Contribution of food items to mean chronic dietary exposure of 3-6 year-old children, France 2007-2009. Shaded cells indicate contributors $>5 \%$. 


\begin{tabular}{|c|c|c|c|c|c|c|c|c|c|}
\hline Food category & As & Cd & $\mathrm{Cr}$ & $\mathrm{Cu}$ & $M n$ & $\mathrm{~Pb}$ & Sb & $\mathrm{Sr}$ & $\mathbf{v}$ \\
\hline Alcoholic drinks & $<1 \%$ & $0 \%$ & $0 \%$ & $<1 \%$ & $<1 \%$ & $<1 \%$ & $<1 \%$ & $<1 \%$ & $0 \%$ \\
\hline Biscuits or crackers and bars & $<1 \%$ & $5 \%$ & $2 \%$ & $3 \%$ & $6 \%$ & $1 \%$ & $3 \%$ & $<1 \%$ & $2 \%$ \\
\hline Bread and dry bread & $1 \%$ & $12 \%$ & $3 \%$ & $5 \%$ & $17 \%$ & $3 \%$ & $2 \%$ & $1 \%$ & $3 \%$ \\
\hline Butter & $<1 \%$ & $<1 \%$ & $3 \%$ & $<1 \%$ & $<1 \%$ & $<1 \%$ & $<1 \%$ & $<1 \%$ & $<1 \%$ \\
\hline Cereals & $<1 \%$ & $<1 \%$ & $2 \%$ & $<1 \%$ & $<1 \%$ & $<1 \%$ & $<1 \%$ & $<1 \%$ & $<1 \%$ \\
\hline Cheese & $1 \%$ & $<1 \%$ & $6 \%$ & $<1 \%$ & $<1 \%$ & $2 \%$ & $2 \%$ & $3 \%$ & $4 \%$ \\
\hline Chocolate & $1 \%$ & $2 \%$ & $3 \%$ & $6 \%$ & $9 \%$ & $1 \%$ & $3 \%$ & $1 \%$ & $1 \%$ \\
\hline Coffee & $0 \%$ & $0 \%$ & $0 \%$ & $<1 \%$ & $<1 \%$ & $0 \%$ & $0 \%$ & $0 \%$ & $0 \%$ \\
\hline Condiments and sauces & $<1 \%$ & $1 \%$ & $1 \%$ & $<1 \%$ & $<1 \%$ & $<1 \%$ & $<1 \%$ & $<1 \%$ & $3 \%$ \\
\hline Delicatessen & $<1 \%$ & $<1 \%$ & $2 \%$ & $2 \%$ & $<1 \%$ & $2 \%$ & $<1 \%$ & $<1 \%$ & $2 \%$ \\
\hline Desserts, puddings and milk jelly & $<1 \%$ & $3 \%$ & $4 \%$ & $3 \%$ & $1 \%$ & $2 \%$ & $1 \%$ & $1 \%$ & $2 \%$ \\
\hline Dried fruits and oilseeds & $<1 \%$ & $<1 \%$ & $<1 \%$ & $1 \%$ & $2 \%$ & $<1 \%$ & $<1 \%$ & $<1 \%$ & $<1 \%$ \\
\hline Dried vegetables & $<1 \%$ & $<1 \%$ & $<1 \%$ & $1 \%$ & $3 \%$ & $1 \%$ & $<1 \%$ & $1 \%$ & $<1 \%$ \\
\hline Eggs and derivatives & $<1 \%$ & $<1 \%$ & $<1 \%$ & $<1 \%$ & $<1 \%$ & $<1 \%$ & $<1 \%$ & $<1 \%$ & $<1 \%$ \\
\hline Fish & $64 \%$ & $<1 \%$ & $1 \%$ & $<1 \%$ & $<1 \%$ & $<1 \%$ & $1 \%$ & $<1 \%$ & $<1 \%$ \\
\hline Foods for special dietary needs & $0 \%$ & $0 \%$ & $0 \%$ & $0 \%$ & $0 \%$ & $0 \%$ & $0 \%$ & $0 \%$ & $0 \%$ \\
\hline Fresh soft drinks & $1 \%$ & $1 \%$ & $4 \%$ & $2 \%$ & $11 \%$ & $8 \%$ & $8 \%$ & $4 \%$ & $9 \%$ \\
\hline Fruits & $<1 \%$ & $1 \%$ & $3 \%$ & $4 \%$ & $7 \%$ & $3 \%$ & $9 \%$ & $2 \%$ & $4 \%$ \\
\hline Ice cream and frozen desserts & $<1 \%$ & $<1 \%$ & $<1 \%$ & $1 \%$ & $<1 \%$ & $<1 \%$ & $<1 \%$ & $<1 \%$ & $<1 \%$ \\
\hline Margarine & $<1 \%$ & $<1 \%$ & $<1 \%$ & $<1 \%$ & $<1 \%$ & $<1 \%$ & $<1 \%$ & $<1 \%$ & $<1 \%$ \\
\hline Meat & $<1 \%$ & $<1 \%$ & $2 \%$ & $2 \%$ & $<1 \%$ & $2 \%$ & $1 \%$ & $<1 \%$ & $<1 \%$ \\
\hline Milk & $5 \%$ & $4 \%$ & $19 \%$ & $2 \%$ & $<1 \%$ & $32 \%$ & $5 \%$ & $4 \%$ & $14 \%$ \\
\hline Mixed dishes & $3 \%$ & $8 \%$ & $4 \%$ & $6 \%$ & $4 \%$ & $2 \%$ & $6 \%$ & $1 \%$ & $4 \%$ \\
\hline Offal & $0 \%$ & $<1 \%$ & $<1 \%$ & $14 \%$ & $<1 \%$ & $<1 \%$ & $<1 \%$ & $<1 \%$ & $<1 \%$ \\
\hline Oil & $<1 \%$ & $<1 \%$ & $4 \%$ & $<1 \%$ & $<1 \%$ & $<1 \%$ & $<1 \%$ & $<1 \%$ & $<1 \%$ \\
\hline Other hot drinks & $<1 \%$ & $<1 \%$ & $<1 \%$ & $<1 \%$ & $<1 \%$ & $<1 \%$ & $<1 \%$ & $<1 \%$ & $<1 \%$ \\
\hline Pasta & $<1 \%$ & $8 \%$ & $5 \%$ & $15 \%$ & $6 \%$ & $<1 \%$ & $5 \%$ & $1 \%$ & $2 \%$ \\
\hline Pastries and cakes & $<1 \%$ & $2 \%$ & $4 \%$ & $2 \%$ & $4 \%$ & $1 \%$ & $11 \%$ & $<1 \%$ & $<1 \%$ \\
\hline Pastries (croissants, etc.) & $<1 \%$ & $1 \%$ & $3 \%$ & $1 \%$ & $3 \%$ & $<1 \%$ & $2 \%$ & $<1 \%$ & $3 \%$ \\
\hline Pizzas, quiches and savory pastries & $<1 \%$ & $2 \%$ & $2 \%$ & $1 \%$ & $2 \%$ & $<1 \%$ & $1 \%$ & $<1 \%$ & $2 \%$ \\
\hline Potatoes and similar & $<1 \%$ & $15 \%$ & $3 \%$ & $4 \%$ & $3 \%$ & $2 \%$ & $1 \%$ & $<1 \%$ & $2 \%$ \\
\hline Poultry and game & $<1 \%$ & $<1 \%$ & $2 \%$ & $1 \%$ & $<1 \%$ & $<1 \%$ & $<1 \%$ & $<1 \%$ & $<1 \%$ \\
\hline Rice and wheat & $<1 \%$ & $2 \%$ & $4 \%$ & $4 \%$ & $4 \%$ & $<1 \%$ & $3 \%$ & $<1 \%$ & $<1 \%$ \\
\hline Sandwich, snack & $<1 \%$ & $<1 \%$ & $<1 \%$ & $<1 \%$ & $<1 \%$ & $<1 \%$ & $<1 \%$ & $<1 \%$ & $<1 \%$ \\
\hline Shellfish and mollusk & $11 \%$ & $4 \%$ & $<1 \%$ & $1 \%$ & $<1 \%$ & $<1 \%$ & $<1 \%$ & $<1 \%$ & $<1 \%$ \\
\hline Soup and stock & $<1 \%$ & $4 \%$ & $2 \%$ & $3 \%$ & $2 \%$ & $6 \%$ & $2 \%$ & $2 \%$ & $6 \%$ \\
\hline Stewed fruit and cooked fruit & $<1 \%$ & $3 \%$ & $1 \%$ & $1 \%$ & $2 \%$ & $3 \%$ & $3 \%$ & $<1 \%$ & $<1 \%$ \\
\hline Sugar and derivatives & $<1 \%$ & $2 \%$ & $<1 \%$ & $<1 \%$ & $<1 \%$ & $<1 \%$ & $8 \%$ & $<1 \%$ & $<1 \%$ \\
\hline Ultra-fresh dairy & $1 \%$ & $1 \%$ & $4 \%$ & $<1 \%$ & $<1 \%$ & $5 \%$ & $5 \%$ & $1 \%$ & $4 \%$ \\
\hline Vegetables (excluding potatoes) & $<1 \%$ & $10 \%$ & $3 \%$ & $4 \%$ & $7 \%$ & $4 \%$ & $6 \%$ & $5 \%$ & $3 \%$ \\
\hline Bottled waters & $2 \%$ & $<1 \%$ & $1 \%$ & $2 \%$ & $<1 \%$ & $9 \%$ & $5 \%$ & $63 \%$ & $23 \%$ \\
\hline
\end{tabular}

Table 2.Contribution of food items to $10 \%$ highest chronic dietary exposure of 3-6 year-old children, France 2007-2009. Shaded cells indicate contributors $>5 \%$. 


\section{Chromium}

Median and P95 children's total and dietary exposure estimates were 10.2, 15.8, 9.91 and $15.6 \mu \mathrm{g} / \mathrm{kg}$ bw/d respectively. More than $97 \%$ of total exposure came via diet. The French food safety agency estimated $10.7 \mu \mathrm{g} / \mathrm{kg} \mathrm{bw} / \mathrm{d}$ and $14.9 \mu \mathrm{g} / \mathrm{kg} \mathrm{bw} / \mathrm{d}$ for mean and P95 (MB) exposure for children between 3 and 6 years old(Anses 2011). For European children, EFSA (EFSA 2014) found a mean dietary exposure of between $2.4 \mu \mathrm{g} / \mathrm{kg} \mathrm{bw} / \mathrm{d}$ and $3.3 \mu \mathrm{g} / \mathrm{kg} \mathrm{bw} / \mathrm{d}$ (LB-UB). Rose found a mean value of between $0.81 \mu \mathrm{g} / \mathrm{kg}$ bw/d and $1.0 \mu \mathrm{g} / \mathrm{kg}$ bw/d (LB-UB) for UK toddlers(Rose et al. 2010), and the Australian TDS (FSANZ 2011) gave a mean value of $4.4 \mu \mathrm{g} / \mathrm{kg} \mathrm{bw} / \mathrm{d}$. Our results are between twice and tentimes higher than these international published estimates. The explanation relies on differences in contamination of the most contributing food items. The most contributing foods are milk ( $13 \%$ increasing to $19 \%$ for the P90 population), then cheese $(6 \%)$, noodles and pasta $(5 \%)$ and milk products $(5 \%)$. This means that milky products contribute to a quarter of dietary exposure to chromium. Considering the EFSA Tolerable Daily Intake for $\mathrm{Cr}$ (III) of $300 \mu \mathrm{g} / \mathrm{kg}$ bw/d (EFSA 2014), chromium exposure is not a health concern. It is important to bear in mind that $\mathrm{Cr}$ (III) is more frequently found that $\mathrm{Cr}(\mathrm{VI})$, which is more harmful, and our hypothesis here is that all $\mathrm{Cr}$ was in the common $\mathrm{Cr}(\mathrm{III})$ form.

\section{Copper}

Median and P95 children's total and dietary exposure estimates were $34.1,61.3,33.6$ and $60.3 \mu \mathrm{g} / \mathrm{kg}$ bw/d respectively. More than $98 \%$ of total exposure came via diet. The French food safety agency obtained $39.1 \mu \mathrm{g} / \mathrm{kg} \mathrm{bw} / \mathrm{d}$ and $62.1 \mu \mathrm{g} / \mathrm{kg}$ bw/d for mean and P95 dietary intake for French children(Anses 2011). For UK children, estimates are $44.7 \mu \mathrm{g} / \mathrm{kg} \mathrm{bw} / \mathrm{d}$ and $77.8 \mu \mathrm{g} / \mathrm{kg} \mathrm{bw} / \mathrm{d}$ for mean and P97.5 values of exposure respectively(Rose et al. 2010). The 2004 Italian TDS obtained $63.3 \mu \mathrm{g} / \mathrm{kg}$ $\mathrm{bw} / \mathrm{d}$ (mean value) and $109 \mu \mathrm{g} / \mathrm{kg} \mathrm{bw/d} \mathrm{(P95)} \mathrm{for} \mathrm{the} \mathrm{general} \mathrm{Italian} \mathrm{population} \mathrm{(Turconi} \mathrm{et.} \mathrm{al} \mathrm{2009).}$ EFSA in its opinion on copper supplementation (EFSA 2009b) evaluated mean copper intake for European children at $1 \mathrm{mg} / \mathrm{d}$ (around $40 \mu \mathrm{g} / \mathrm{kg}$ bw/d). All these values are in good agreement. The most contributing foods are pasta or noodles (14\%) and then fruits (6\%). For the P90 population, offalmade a $14 \%$ contribution. The high contribution of noodles is due to their high level of contamination ( $3 \mu \mathrm{g} / \mathrm{g}$, where median contamination for food is $0.7 \mu \mathrm{g} / \mathrm{g}$ ). For offal, the explanation is also high contamination (113 $\mu \mathrm{g} / \mathrm{g}$ )rather than consumption, which is low. There is no reference value for risk assessment but a safety limit was proposed by the Scientific Committee on Food (SCF 2003)at the value of $2 \mathrm{mg} / \mathrm{d}$ (around $111 \mu \mathrm{g} / \mathrm{kg}$ bw/d). Copper is thus not a health concern for children.

\section{Manganese}

Median and P95 children's total and dietary exposure estimates were $60.3,98.3,57.1$ and $94.9 \mu \mathrm{g} / \mathrm{kg}$ bw/d respectively. More than $95 \%$ of total exposure came via diet. The French food safety agency calculated French children's daily intake at $62.7 \mu \mathrm{g} / \mathrm{kg}$ bw/d (mean value) and $101 \mu \mathrm{g} / \mathrm{kg} \mathrm{bw} / \mathrm{d}$ (P95)(Anses 2011). UK toddlers' intake was evaluated at $168 \mu \mathrm{g} / \mathrm{kg}$ bw/d (mean value) and $305 \mu \mathrm{g} / \mathrm{kg}$ bw/d (P97.5)(Rose et al. 2010). Turconi evaluated Italian children's intake at a mean value of 75.6 $\mu \mathrm{g} / \mathrm{kg} \mathrm{bw} / \mathrm{d}$ and a P95 of $122 \mu \mathrm{g} / \mathrm{kg}$ bw/d (Turconi et al. 2009). EFSA (EFSA 2013) published intakes for European children, which are the same order of magnitude as French children, with the exception ogPortugal (twice the French level) and Slovenia (four times the French level). The most contributing foods were bread $(14 \%)$, followed by noodles $(9 \%)$, vegetables $(8 \%)$ and biscuits $(8 \%)$. For the P90 
children population, bread increased to $17 \%$, and then and chilled drinks (11\%) and chocolate (9\%) appear. For chocolate, the main contributor is soft chocolate margarine $192 \%$ of this category contribution). For chilled drink, the main contributor is pineapple juice (69\% of this category contribution). These two last products contribute because of their high contamination $(12.3 \mu \mathrm{g} / \mathrm{g}$ for chocolate and $14.6 \mu \mathrm{g} / \mathrm{g}$ for pineapple) compared to a median food contamination of $0.6 \mu \mathrm{g} / \mathrm{g}$. There is no TDI for manganese. The US Institute of Medicine proposed an adequate intake for children aged 1 to 3 years old at $1 \mathrm{mg} / \mathrm{d}$, around $50 \mu \mathrm{g} / \mathrm{kg} \mathrm{bw} / \mathrm{d}$ (EFSA 2013). Manganese intake is thus at a good level.

Lead

Median and P95 children's total and dietary exposure estimates were $0.71,2.52,0.37$ and $0.42 \mu \mathrm{g} / \mathrm{kg}$ bw/d respectively. Diet contributed to half of exposure at the mean - whereas for the most exposed, soil and dust ingestion were the pathways contributing most, as discussed below in a specific paragraph, together with a comparison with toxicity data. For French children aged 3-17 years, Arnich(Arnich et al. 2012) estimated dietary intake as $0.3 \mu \mathrm{g} / \mathrm{kg}$ bw/d. In Germany, median and P90 intakes were evaluated 0.4 and $0.6 \mu \mathrm{g} / \mathrm{kg} \mathrm{bw} / \mathrm{d}$ respectively(Schrey et al. 2000). In the UK, median and P97.5 intakes were evaluated at 0.21-0.25 and 0.38-0.42 $\mu \mathrm{g} / \mathrm{kg}$ bw/d respectively(Rose et al. 2010). Other European estimatesreported by EFSA (EFSA 2010) may be higher, due to higher quantification limits. Dietary lead exposure is mainly due to milk (15\%), fresh drinks (11\%), then vegetables (6\%) and bread (6\%).

\section{Antimony}

Median and P95 children's total and dietary exposure estimates were $0.08,0.12,0.06$ and $0.08 \mu \mathrm{g} / \mathrm{kg}$ bw/d respectively. More than $77 \%$ of total exposure came via diet (67\% for the P95 of exposure). Arnich(Arnich et al. 2012) obtained a mean dietary intake for French children of between $0.04 \mu \mathrm{g} / \mathrm{kg}$ $\mathrm{bw} / \mathrm{d}$ and $0.06 \mu \mathrm{g} / \mathrm{kg} \mathrm{bw} / \mathrm{d}$ (LB-UB) using the French TDS. The small difference between this and our results originates in the demographic, which is older in Arnich's evaluation (3-17 years old). Rose et al.(2010) obtained $0.075-0.077 \mu \mathrm{g} / \mathrm{kg}$ bw/ $\mathrm{d}$ as the mean intake for toddlers from the UK(Rose et al. 2010). The European Union Risk Assessment Report (EU 2008) evaluated European diet intake at around $0.15 \mu \mathrm{g} / \mathrm{kg}$ bw/d,using analysis of European pregnant women. The difference between this and other studies can be explained by the probable different limits of quantification, the European report being older (initial paper in 2002). The most contributing foods were pastries (9\%), sugar (7\%) and noodles (6\%). For the P90 population contributors were pastries (11\%), fruits (9\%) and sugar (8\%). No single food appears as a major contributor in any of these categories. The WHO (2003) published a TDI of $6 \mu \mathrm{g} / \mathrm{kg} \mathrm{bw} / \mathrm{d}$, showing no health concern for children.

\section{Strontium}

Median and P95 children's total and dietary exposure estimates were 44.3, 111, 39.4 and $103 \mu \mathrm{g} / \mathrm{kg}$ bw/d respectively. More than $90 \%$ of total exposure came via diet, and $9 \%$ from tap water. The French food safety agency (2011) obtained a mean dietary intake of $42.8 \mu \mathrm{g} / \mathrm{kg} \mathrm{bw} / \mathrm{d}$, and a P95 of 78 $\mu \mathrm{g} / \mathrm{kg} \mathrm{bw} / \mathrm{d}$ (Anses 2011). The difference between these two results originates in the modeling of water consumption (which though similar, is not identical) - although the order of magnitude is the same. Rose et al. obtained $42.8 \mu \mathrm{g} / \mathrm{kg} \mathrm{bw} / \mathrm{d}$ for toddlers in the UK. Turconiobtained a mean of 63.3 $\mathrm{mg} / \mathrm{kg} \mathrm{bw} / \mathrm{d}$ and a P95 of $104 \mu \mathrm{g} / \mathrm{kg}$ bw/d for Italian children (Turconi et al. 2009). Total exposure to 
strontium was evaluated at $50 \mu \mathrm{g} / \mathrm{kg}$ bw/d by the International Program on Chemical Safety (IPCS 2010). All these results are in good agreement. The most contributing foods were bottled water (33\%), then vegetables (8\%) and milk (7\%). For the most exposed (P90), the contribution made by bottled water was as high as $63 \%$. If tap water contribution is added, between $42 \%$ and $62 \%$ of the mean exposure comes from water (tap and bottled). The US EPA proposed a subchronic reference dose of $600 \mu \mathrm{g} / \mathrm{kg}$ bw/d in 1996. The International Program on Chemical Safety(2010) proposed a TDI of $130 \mu \mathrm{g} / \mathrm{kg} \mathrm{bw} / \mathrm{d}$. Strontium is thus not of health concern for children.

\section{Vanadium}

Median and P95 children's total and dietary exposure estimates were 1.52, 2.85, 1.31 and $2.5 \mu \mathrm{g} / \mathrm{kg}$ bw/d respectively. More than $85 \%$ of total exposure came via diet. The French food safety agency calculated a mean daily intake of $1.5 \mu \mathrm{g} / \mathrm{kg}$ bw/d, and a P95 of $2.8 \mu \mathrm{g} / \mathrm{kg}$ bw/d(Anses 2011). Turconi found a mean exposure of $0.7 \mu \mathrm{g} / \mathrm{kg}$ bw/d and a P95 of $1.0 \mu \mathrm{g} / \mathrm{kg} \mathrm{bw} / \mathrm{d}$ for the general Italian population(Turconi et al. 2009). EFSA evaluated the mean intake of $10-20 \mu \mathrm{g} /$ person/d (corresponding to $0.3-0.7 \mu \mathrm{g} / \mathrm{kg}$ bw/d)(EFSA 2004), which implies a child intake of $0.5-1.0 \mu \mathrm{g} / \mathrm{kg}$ $\mathrm{bw} / \mathrm{d}$. All these evaluations are in the same order of magnitude. The most contributing foods were water (13\%) and milk (12\%), increasing to $23 \%$ for water and $14 \%$ for milk, for the most exposed population (P90). For the water group, plain water is the highest contributor (60\% to $68 \%$ for mean population and $\mathrm{P} 90)$. For the milk group, half skimmed milk is the highest contributor (92\%). As its contamination is of the same level of magnitude as other food, this contribution is due to higher consumption. No TDI exists for vanadium. EFSA considered (EFSA 2004) that a margin of exposure of 1000 exists when considering the lowest doses reported to cause adverse effects in rats. This corresponds to a MoEof above $\mathbf{3 0 0}$ for our estimates for children,meaning that the risk cannot be ruled out.

\subsection{The case of lead}

Figure 2, which focuses on lead exposure, confirms that this predominance of residential exposure is true even at the $98^{\text {th }}$ percentile, with a great variability (symbolized by error bars on the figure) among children. 


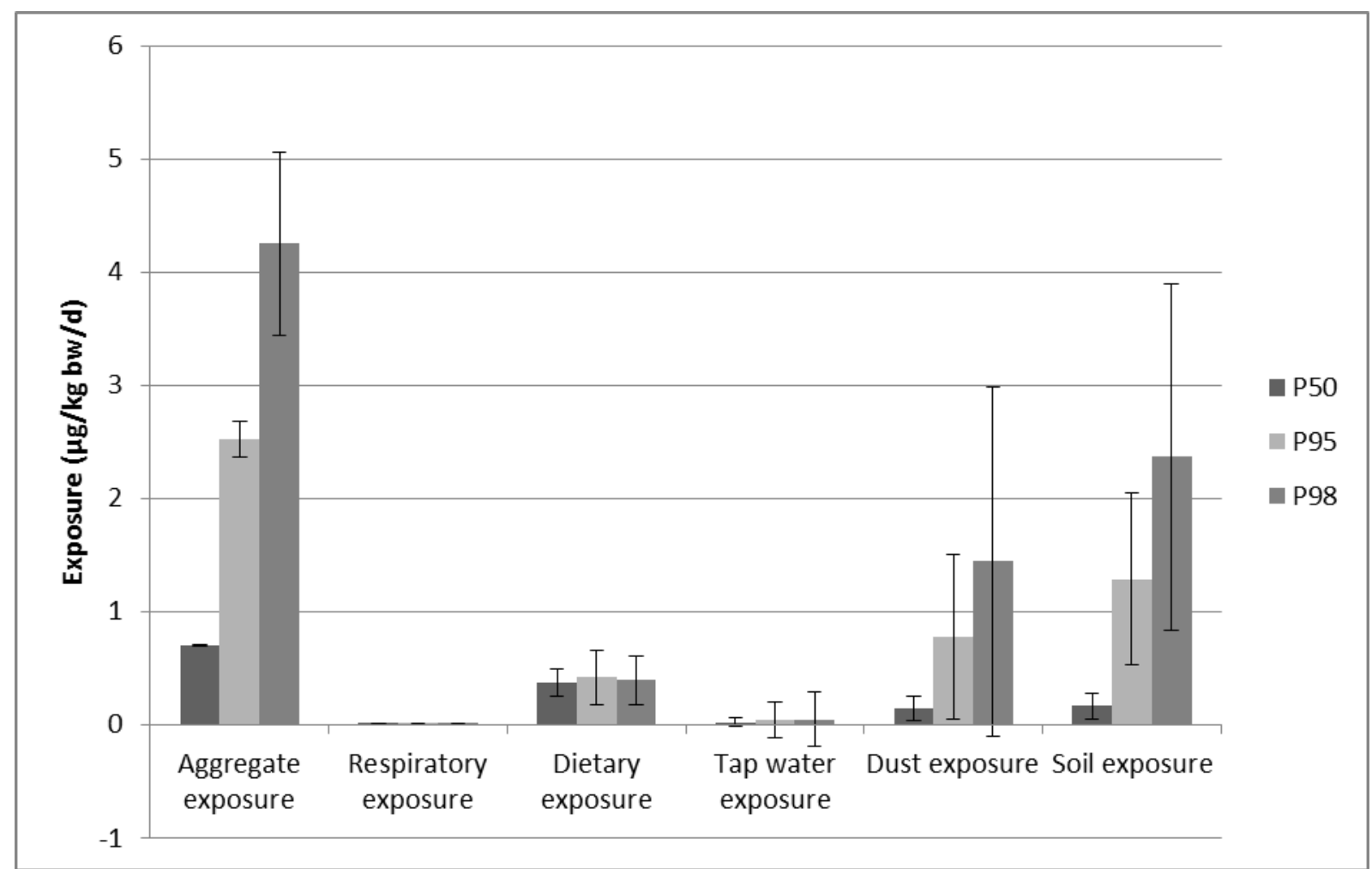

Figure 2. Exposure to lead among children aged 3-6 years, France 2007-2009. Error bar: 1 standard deviation.

The possibility of comparison with previous estimates is limited by the availability of similar studies. Based on similar design but older and non-specific environmental data, a previous study (Glorennec et. al 2007)found a slightly lower overall intake (median $4.7 \mu \mathrm{g} / \mathrm{kg} /$ week for 3-6 years) with a greater contribution made by diet, and a lesser one by soil and dust. Differences in dietary intake may be due to lower quantifications limits. The greater significance of soil and dust in our study is drawn from concentration data, in comparison with default values used in previous study(data came from other countries for soil and from a specific region for dust). The concentrations used here are similar in median, yet more elevated for higher percentiles.

Almost $80 \%$ of children aged 3-6 years have a total dose in excess of $0.5 \mu \mathrm{g} / \mathrm{kg}$ bw/d, which is the equivalent dose to the benchmark dose of $12 \mu \mathrm{g} / \mathrm{L}$ (blood), corresponding to 1 IQ point loss (BudtzJorgensen et. al 2013; EFSA 2010). This is consistent with the observed blood lead levels (BLL) $(\mathrm{GM}=15 \mu \mathrm{g} / \mathrm{L}, \mathrm{P} 25=11 \% \mathrm{~g} / \mathrm{L}$ ) in this age group in 2008-2009(Etchevers et al. 2014). Food ingestion contributes to half the median total dose, whereas dust and soil contribute equally to the other half. The situation is different for the most exposed, with soil - and particularly dust ingestion - becoming the major pathways. This contribution of dust is in line with recent findings in France (Etchevers et. al 2015; Oulhote et al. 2013) indicating that interior floor dust was, along with soil and water, associated with the greatest increase in BLLS (about 50\% more when dust loading increases from 1 to $10 \mu \mathrm{g} / \mathrm{m}^{2}$ (Oulhote et al. 2013), for instance). This important contribution of indoor dust has also been recently observed in North-America(Dixon et. al 2009; Levallois et. al 2013).

Soil and dust ingestion rates are both variable and uncertain parameters, with low confidence estimates(EPA 2011). This subject is also hotly debated in the literature, especially by Stanek who conducted a meta-analysis on soil ingestion studies (Stanek et. al 2012)and estimated the soil 
ingestion mean to be $25.5 \mathrm{mg} /$ day (+/- $15.5 \mathrm{mg} /$ day). In the discussion, the author stated it concerned only soil (and not dust ingestion) although the trace-element methodology used in primary studies was not able to distinguish dust from soil. This uncertainty in the definition of soil and dust ingestion, coupled with uncertainty aboutthe value of the parameter, results in an uncertainty aboutthe amount of lead ingested both by soil and dust. Actually dividing the quantity of ingested soil and dust by 2 or 4 in the simulation would certainly result in a lower contribution from dust and soil,as well as total doses that would mainly be driven by dietary exposures - with the exception of the most exposed. Moreover, we have not taken into account the bioavailability of soil and dust relative to food, because of the absence of data about lead bioavailability. In French soils and dust, bioaccessibility has been shown (using a leachability test in vitro) to vary greatly between samples, and $\mathrm{Pb}$ had a median leachability in excess of $75 \%$ (Glorennec et al. 2012). In order to assess the consistency of our results for lead with observed BLL, we used the Integrated Exposure Uptake BioKinetic model for lead in children (IEUBK)(White et. al 1998) to model the BLL from our data. We ran IEUBK with the median dietary and environmental data simulated across all children. We used default parameters for other inputs, notably soil and dust ingestion, from 0.90 to 0.135 depending on age). We found that predicted mean BLLs were 13-16 $\mu \mathrm{g} / \mathrm{L}$ - very close to those observed $(15 \mu \mathrm{g} / \mathrm{L})($ Etchevers et al. 2014). Modeled 95th percentiles (around $30 \mu \mathrm{g} / \mathrm{L}$ ) were also close to those observed.

For the vast majority of children, the contribution of air and water is minimal. This assessment gives a picture at a country level, given the concurrent exposures; it must not be interpreted as encompassing all situations, and in particular extreme or infrequent ones. For example, in our results, tap water has a minimal contribution to lead exposure: this is due to frequent low concentrations. Nevertheless, for a $10 \mathrm{~kg}$ child drinking $0.5 \mathrm{~L}$ of water containing $10 \mu \mathrm{g}(\mathrm{Pb}) / \mathrm{L}$, tap water will substantially contribute to the intake $(0.5 \mu \mathrm{g} / \mathrm{kg} \mathrm{bw} / \mathrm{d}$ for water alone in our example). Our results simply show that this situation is infrequent. In addition, water lead concentration was shown to have an impact on BLL in France.

This study was, by design, dedicated to the exposure of most of the children, and must not be inferred to specific situations. It is limited to the home environment (that most frequented by children) and most consumed food items. $90 \%$ of diet is considered, so specific populations with specific habits may be excluded. It may tend to underestimate the contribution of diet for the most exposed, as do the grouping of food items before analysis. Especially when diet is the dominating source of exposure, it tends to underestimate the aggregate exposure. More generally, the study encompasses the main sources of exposures at population level but is not designed to point out specific sources for particularly exposed children. For example, traditional dishes or cosmetics have been associated with high BLL(Etchevers et al. 2015)yet were not considered as a source of exposure. An indoor environment not included here although frequented by older children is schools; representative data are not available but a few measurements in French schools (Canha et. al 2015)indicate that dust usually contains very low metal concentrations. Air concentration data were neither numerous (and absent for Sr) nor representative - but the respiratory pathway appeared to be negligible so that uncertainty on these concentrations distributions do not affect the results of the exposure assessment. 


\section{Conclusions}

In this study we aggregated dietary and environmental chronic exposures to nine inorganic trace elements ( $\mathrm{As}, \mathrm{Cd}, \mathrm{Cr}, \mathrm{Cu}, \mathrm{Mn}, \mathrm{Pb}, \mathrm{Sb}, \mathrm{Sr}, \mathrm{V}$ ), although exposures are traditionally estimated separately for diet and environment. Exposure estimates rely on data that are numerous, homogeneous and representative of 3-6 years old children and their chronic exposures. Though quantitative estimates are uncertain, they do allow identification of the source of exposure contributing most to overall exposure, and meriting continued prevention efforts.Aggregate exposure of concern are As with importance of fish and seafood contribution in which however As is in a lesser toxic form, $\mathrm{Cd}, \mathrm{Pb}$, and may be $\mathrm{V}$, Another important key finding is that for elements other than lead, diet dominates exposure, and that non dietary intakes are of great importance for children the most exposed to lead. A practical implication in the regulatory arena is that when setting standards for lead in food, other exposures have to be taken into account carefully. Also interpreting lead dietary intakes cannot be complete without perspective to soil and dust exposures.

\section{Acknowledgments}

This work was funded by the French Ministry of Ecology, which did not take part in designing or interpreting the study.

The authors are grateful to NawelBemrah (Anses - French food and environment safety agency) for her help in matching diet consumption and contamination surveys.

The authors are grateful to Jane Roffe for scientific editing. 
Anses. Étude de l'alimentation totale française 2 (EAT 2) Tome 1 . Agence nationale de sécurité sanitaire de l'alimentation, de l'environnement et du travail; 2011

Arnich, N.; Sirot, V.; Riviere, G.; Jean, J.; Noel, L.; Guerin, T.; Leblanc, J.C. Dietary exposure to trace elements and health risk assessment in the 2nd French Total Diet Study. Food ChemToxicol. 50:2432-2449; 2012

Bonanno, L.J.; Freeman, G.; Greenberg, M.; Lioy, P.J. Multivariate analysis on levels of selected metals, particulate matter, VOC, and household characteristics and activities from the Midwestern states NHEXAS. Applied Occupational and Environmental Hygiene. 16:859-874; 2001

Budtz-Jorgensen, E.; Bellinger, D.; Lanphear, B.; Grandjean, P. An international pooled analysis for obtaining a benchmark dose for environmental lead exposure in children. Risk Anal. 33:450461; 2013

Canha, N.; Mandin, C.; Ramalho, O.; Wyart, G.; Ribéron, J.; Dassonville, C.; Derbez, M. Exposure Assessment of Allergens and Metals in Settled Dust in French Nursery and Elementary Schools. Atmosphere. 6:1676-1694; 2015

Dixon, S.L.; Gaitens, J.M.; Jacobs, D.E.; Strauss, W.; Nagaraja, J.; Pivetz, T.; Wilson, J.W.; Ashley, P.J. Exposure of U.S. children to residential dust lead, 1999-2004: II. The contribution of leadcontaminated dust to children's blood lead levels. Environ Health Perspect. 117:468-474; 2009

Dzubay, T.G.; Stevens, R.K. Ambient air analysis with dichotomous sampler and X-ray fluorescence spectrometer. Environmental science \& technology. 9:663-668; 1975

EFSA. Opinion of the Scientific Panel on Dietetic Products, Nutrition and Allergies on a request from the Commission related to the Tolerable Upper Intake Level of Vanadium. EFSA J:22; 2004

EFSA. Cadmium in food - Scientific opinion of the Panel on Contaminants in the Food Chain. Parma: European Food Safety Authority; 2009a

EFSA. Copper(II) oxide as a source of copper added for nutritional purposes to food supplements. EFSA Journal:15; 2009b

EFSA. Panel on contaminants in the food chain (CONTAM); scientific opinion on arsenic in food. EFSA J. 7:1351; 2009c

EFSA. Scientific Opinion on Lead in Food. EFSA Journal: European Food Safety Agency; 2010

EFSA. Scientific Opinion on Dietary Reference Values for manganese. EFSA Journal. 11:44; 2013

EFSA. Scientific Opinion on the risks to public health related to the presence of chromium in food and drinking water. EFSA Journal: European Food Safety Authority; 2014

EPA, U.S. Exposure factors handbook. Washington (US): United States Environmental Protection Agency; 2011

Etchevers, A.; Bretin, P.; Lecoffre, C.; Bidondo, M.L.; Le Strat, Y.; Glorennec, P.; A., L.T. Blood lead levels and risk factors in young children in France, 2008-2009. IntJHygEnvironHealth. 217:528-537; 2014

Etchevers, A.; Le Tertre, A.; Lucas, J.P.; Bretin, P.; Oulhote, Y.; Le Bot, B.; Glorennec, P. Environmental determinants of different blood lead levels in children: a quantile analysis from a nationwide survey. Environment international. 74:152-159; 2015

EU. European Union Risk Assessment Report. Diantimony trioxide Risk assessment. Sundbyberg, Sweden: Swedish Chemicals Inspectorate; 2008

FSANZ. 23rd Australian Total Diet Study. Food Standards Autralia New Zealand; 2011

Giovannangelo, M.; Nordling, E.; Gehring, U.; Oldenwening, M.; Bellander, T.; Heinrich, J.; Hoek, G.; Brunekreef, B. Variation of biocontaminant levels within and between homes--the AIRALLERG study. JExpoSciEnvironEpidemiol. 17:134-140; 2007

Glorennec, P.; Bemrah, N.; Tard, A.; Robin, A.; Le Bot, B.; Bard, D. Probabilistic modeling of young children's overall lead exposure in France: Integrated approach for various exposure media. EnvironInt:937-945; 2007 
Glorennec, P.; Le Bot, B.; Saramito, G.; Arcelin, C. Exposures to lead via dust ingestion of french children: a pilot study. 15th annual conference of International Society for Exposure Analysis. Tucson Az, USA.; 2005

Glorennec, P.; Lucas, J.P.; Mandin, C.; Le Bot, B. French children's exposure to metals via ingestion of indoor dust, outdoor playground dust and soil: Contamination data. Environ Int. 45:129-134; 2012

Grandjean, P.; Bellinger, D.; Bergman, A.; Cordier, S.; vey-Smith, G.; Eskenazi, B.; Gee, D.; Gray, K.; Hanson, M.; van den, H.P.; Heindel, J.J.; Heinzow, B.; Hertz-Picciotto, I.; Hu, H.; Huang, T.T.; Jensen, T.K.; Landrigan, P.J.; McMillen, I.C.; Murata, K.; Ritz, B.; Schoeters, G.; Skakkebaek, N.E.; Skerfving, S.; Weihe, P. The faroes statement: human health effects of developmental exposure to chemicals in our environment. Basic ClinPharmacolToxicol. 102:73-75; 2008

IPCS. Strontium and strontium compounds. Geneva: International Program on Chemical Safety; 2010

Le Bot, B.; Lucas, J.P.; Lacroix, F.; Glorennec, P. Exposure of children to metals via tap water ingestion at home: Contamination and exposure data from a nationwide survey in France. Environment international. 94:500-507; 2016

Leufroy, A.; Noel, L.; Dufailly, V.; Beauchemin, D.; Guerin, T. Determination of seven arsenic species in seafood by ion exchange chromatography coupled to inductively coupled plasma-mass spectrometry following microwave assisted extraction: method validation and occurrence data. Talanta. 83:770-779; 2011

Levallois, P.; St-Laurent, J.; Gauvin, D.; Courteau, M.; Prevost, M.; Campagna, C.; Lemieux, F.; Nour, S.; D'Amour, M.; Rasmussen, P.E. The impact of drinking water, indoor dust and paint on blood lead levels of children aged 1-5 years in Montreal (Quebec, Canada). J ExpoSciEnviron Epidemiol; 2013

Lioret, S.; Dubuisson, C.; Dufour, A.; Touvier, M.; Calamassi-Tran, G.; Maire, B.; Volatier, J.L.; Lafay, L. Trends in food intake in French children from 1999 to 2007: results from the INCA (etude Individuelle Nationale des Consommations Alimentaires) dietary surveys. The British journal of nutrition. 103:585-601; 2010

Lioy, P.J.; Rappaport, S.M. Exposure science and the exposome: an opportunity for coherence in the environmental health sciences. Environ Health Perspect. 119:A466-A467; 2011

Llobet, J.M.; Falco, G.; Casas, C.; Teixido, A.; Domingo, J.L. Concentrations of arsenic, cadmium, mercury, and lead in common foods and estimated daily intake by children, adolescents, adults, and seniors of Catalonia, Spain. Journal of agricultural and food chemistry. 51:838$842 ; 2003$

Lucas, J.P.; Le Bot, B.; Glorennec, P.; Etchevers, A.; Bretin, P.; Douay, F.; Sebille, V.; Bellanger, L.; Mandin, $C$. Lead contamination in French children's homes and environment. Environ Res. $116: 58-65 ; 2012$

Nordberg, G.F.; Fowler, B.A.; Nordberg, M. Handbook on the Toxicology of Metals: Academic Press; 2014

Oulhote, Y.; Le Tertre, A.; Etchevers, A.; Le Bot, B.; Lucas, J.P.; Mandin, C.; Le Strat, Y.; Lanphear, B.; Glorennec, P. Implications of different residential lead standards on children's blood lead levels in France: predictions based on a national cross-sectional survey. IntJHygEnvironHealth. 216:743-750; 2013

Ozkaynak, H.; Xue, J.; Zartarian, V.G.; Glen, G.; Smith, L. Modeled estimates of soil and dust ingestion rates for children. Risk Anal. 31:592-608; 2011

Rose, M.; Baxter, M.; Brereton, N.; Baskaran, C. Dietary exposure to metals and other elements in the 2006 UK Total Diet Study and some trends over the last 30 years. Food additives \& contaminants Part A, Chemistry, analysis, control, exposure \& risk assessment. 27:1380-1404; 2010

SCF. Opinion of the Scientific Committee on Food on the tolerable upper intake level of copper. Scientific Committee on Food, European commission; 2003 
Schrey, P.; Wittsiepe, J.; Budde, U.; Heinzow, B.; Idel, H.; Wilhelm, M. Dietary intake of lead, cadmium, copper and zinc by children from the German North Sea island Amrum. IntJHygEnvironHealth. 203:1-9; 2000

Sirot, V.; Volatier, J.L.; Calamassi-Tran, G.; Dubuisson, C.; Menard, C.; Dufour, A.; Leblanc, J.C. Core food of the French food supply: second Total Diet Study. Food additives \& contaminants Part A, Chemistry, analysis, control, exposure \& risk assessment. 26:623-639; 2009

Stanek, E.J., III; Calabrese, E.J.; B., X. Meta-Analysis of Mass-Balance Studies of Soil Ingestion in Children. Risk Anal. 32:433-447; 2012

Turconi, G.; Minoia, C.; Ronchi, A.; Roggi, C. Dietary exposure estimates of twenty-one trace elements from a Total Diet Study carried out in Pavia, Northern Italy. British journal of nutrition. 101:1200-1208; 2009

White, P.D.; Van Leeuwen, P.; Davis, B.D.; Maddaloni, M.; Hogan, K.A.; Marcus, A.H.; Elias, R.W. The conceptual structure of the integrated exposure uptake biokinetic model for lead in children. EnvironHealth Perspect. 106 Suppl 6:1513-1530; 1998

WHO. Human biomonitoring: facts and figures.: World Health Organization Regional Office for Europe; 2015

Wilhelm, M.; Wittsiepe, J.; Schrey, P.; Lajoie-Junge, L.; Busch, V. Dietary intake of arsenic, mercury and selenium by children from a German North Sea island using duplicate portion sampling. Journal of trace elements in medicine and biology : organ of the Society for Minerals and Trace Elements. 17:123-132; 2003 